\title{
Pharmacological aspects
}

\section{Immunological aspects of the treatment of depression and schizophrenia}

\author{
Norbert Müller, $M D, P h D$
}

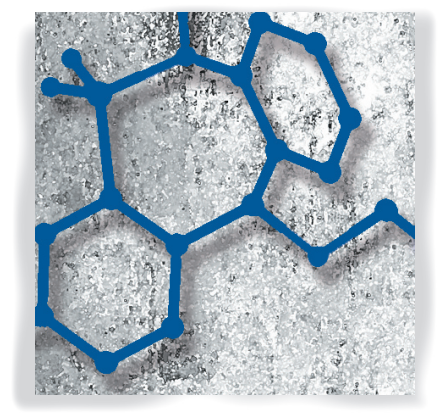

Schizophrenia and major depression (MD) have been associated with immune system dysfunction. One example of this is the altered level of cytokines-important inflammatory mediators-in blood, and a proinflammatory immune state has been described in some subgroups of patients. A knock to the immune system in early life might trigger a life-long increased immune reactivity, and infections and autoimmune disorders are now known to be risk factors for development of schizophrenia and MD. Pro- and anti-inflammatory cytokines mediate indoleamine 2,3-dioxygenase activity; this enzyme drives metabolism of tryptophan and kynurenin in the central nervous system and degrades serotonin. Alterations of serotonergic, noradrenergic, and glutamatergic neurotransmission have been associated with low-level neuroinflammation, and anti-inflammatory compounds have a therapeutic benefit in MD and schizophrenia, as shown in meta-analyses. Moreover, antidepressants and antipsychotics have intrinsic immunomodulatory effects. With evidence pointing to the role inflammatory processes play in the pathogenesis of major psychiatric disorders, this review will look at various immunological aspects of treatment of such disorders.

๑ 2017, AlCH - Servier Research Group

Dialogues Clin Neurosci. 2017;19:55-63.

Keywords: COX-2 inhibition; inflammation; major depression; psychoneuroimmunology; schizophrenia

\author{
Introduction
}

$\mathrm{n}$ immune-based therapeutic approach in psychiatry is not a particularly new idea; it was actually introduced in the early 1900s when the Austrian physician Julius Ritter Wagner von Jauregg created a "vaccination therapy" for psychiatric patients. Although promising - he treated patients successfully with attenuated pathogens that stimulated the type 1 immune response-such an approach would not be pursued outside German-speaking countries, taking a back seat to the newly introduced electroconvulsive therapy and, later, antidepressant and antipsychotic drug therapies.

The basis for this therapeutic approach was built on the observations of several researchers from Austria, Switzerland, Germany, and other countries, which were summarized by Wagner von Jauregg, as a kind of meta-analysis of evidence from the 19th century. It was noted that during and after typhus epidemics, patients were more seldom affected by infections than the staff of the asylum; the infection rate was roughly half that of the staff. ${ }^{1}$ However, in the event that patients were infected, this had an impact on the course of their psychiatric symptoms: about one-third (32\%) of the patients showed improvement in the mental disorder and $20 \%$ became healthy. Based on these observations, Wagner von Jauregg worked on a method

Author affiliations: Department of Psychiatry and Psychotherapy, Ludwig-Maximilian University Munich, Munich, Germany

Address for correspondence: Prof Dr med Dipl-Psych Norbert Müller, Department of Psychiatry and Psychotherapy, Ludwig-Maximilian University, Nussbaumstr 7, 80336 Munich, Germany

(email: Norbert.Mueller@med.uni-muenchen.de) 


\section{Pharmacological aspects}

\author{
Selected abbreviations and acronyms \\ COX-2 cyclooxygenase-2 \\ $\mathbf{I}^{2} \quad$ heterogeneity statistic \\ IDO indoleamine 2,3-dioxygenase \\ IFN interferon \\ IL interleukin \\ KYNA kynurenic acid \\ MD major depression \\ NSAID nonsteroidal anti-inflammatory drug \\ QUIN quinolinic acid \\ TNF tumor necrosis factor
}

to induce artificial fever in the patients using attenuated strains of Salmonella typhii, Malaria tertiana, and the tuberculin protein. He observed the best effects in syphilis (and would win the Nobel Prize for his discovery), but also described therapeutic success in other psychiatric disorders. ${ }^{1}$

After nearly 60 years of psychopharmacotherapy, the limitations are evident: Whereas first- and secondgeneration antipsychotics show satisfying effects on schizophrenia's positive symptoms (eg, hallucinations and delusions), the effects on negative symptoms and cognitive deficits-syndromes determining the longterm outcome in schizophrenia-are unsatisfying. The fact that the discontinuation of antipsychotics is associated with a relapse rate of $80 \%$ in the first 2 years $^{2}$ underscores that the treatment of antipsychotic drugs has nearly no therapeutic influence on the (to date still unknown) pathogenesis of the disorder. Although dopaminergic neurotransmission is very important in schizophrenia, and serotonergic/noradrenergic neurotransmission, in major depression (MD), the neurotransmitter disturbances alone cannot explain the pathological process in psychiatric disorders, and modulation of the dopaminergic and the serotonergic/noradrenergic systems often does not achieve the therapeutic goals.

Despite the dominance of neurotransmitter research in biological psychiatry, psychoneuroimmunology has developed over recent decades, investigating the role of immune dysfunction and inflammation in major psychiatric disorders. Although the overall picture is far from clear, it is now widely accepted that a disturbance in the immune system does play a role in at least some subgroups of patients suffering from schizophrenia or MD. However, few immunomodulatory therapeutic in- terventions are reported in the literature, and even the therapeutic principles-anti-inflammation versus immune activation-are under discussion.

\section{Inflammation and major depression}

It is known that in MD, the inflammatory response system is activated. ${ }^{3-9}$ Although the levels of some markers of inflammation, such as C-reactive protein, tumor necrosis factor (TNF)- $\alpha$, interleukin (IL)-1, and IL-1 receptor antagonist differ between studies, it is clear that IL-6 levels are elevated in MD patients, as evidenced by two meta-analyses. ${ }^{10,11}$ Moreover, MD is often triggered by stress, and stress activates the immune system; in particular, early-life stress and separation stress, their effects influenced by genetic disposition, are associated with elevated levels of proinflammatory cytokines. These cytokines activate the immune system and proinflammatory prostaglandins, such as prostaglandin $\mathrm{E}_{2}$ $\left(\mathrm{PGE}_{2}\right)$, which has an important role in mediating inflammation. ${ }^{12}$ Indeed, $\mathrm{PGE}_{2}$ levels are high in the saliva, serum, and cerebrospinal fluid of depressed patients. ${ }^{13-16}$ Proinflammatory molecules are also produced and released in the brain, where activation of microglia cells and astrocytes plays a key role. Here, interactions in play between the immune system and neurotransmitters, the tryptophan/kynurenine system, and neurotransmission via the glutametergic system provide links between the immune system, stress, and depression. Accordingly, anti-inflammatory therapy, eg, with the cyclooxygenase-2 (COX-2) inhibitor celecoxib-COX-2 being involved in $\mathrm{PGE}_{2}$ mediation of inflammation-is effective in depression.

\section{Nonsteroidal anti-inflammatory drug therapy (in particular, COX-2 inhibitors) in major depression}

COX-2 inhibitors (a type of nonsteroidal anti-inflammatory drugs [NSAID]) influence the serotonergic system in the central nervous system (CNS), both directly and through immune mechanisms in the CNS. In a rat model, rofecoxib increases serotonin levels in the frontal and the temporoparietal cortex. ${ }^{17}$ Therefore, one would expect treatment with COX-2 inhibitors to have a clinical antidepressant effect. In one animal model of depression - the bulbectomized rat-longterm treatment with celecoxib was associated with decreased cytokine levels in the hypothalamus and 
behavioral changes. ${ }^{18}$ In another animal model of depression, add-on treatment with acetylsalicylic acid, a mixed COX-1/COX-2 inhibitor, sped up fluoxetine's antidepressant effect and resulted in an additional antidepressant effect. ${ }^{19}$ In a randomized, double-blind add-on study comparing treatment with reboxetine plus COX-2 inhibitor celecoxib and reboxetine plus placebo in humans, celecoxib had a significant therapeutic effect for MD. ${ }^{20}$ Interestingly, the kynurenine to tryptophan ratio, representing the activity of the proinflammatory cytokine-driven enzyme indoleamine 2,3-dioxygenase (IDO), was predictive of the antidepressant response to celecoxib therapy: those with a high kynurenine-to-tryptophan ratio and thus high IDO enzymatic activity-representing an elevated level of proinflammatory activity-responded better to celecoxib. ${ }^{21}$ In another randomized, double-blind study that included $50 \mathrm{MD}$ patients, outcomes were significantly better in patients treated with celecoxib plus fluoxetine than with fluoxetine plus placebo. ${ }^{22,23} \mathrm{~A}$ similar finding was recently reported in a study including 40 depressed patients randomized to treatment with a combination of sertraline and celecoxib or sertraline and placebo. ${ }^{24}$ Of note, the level of IL-6 in the blood was predictive of the antidepressant response in both groups.

A meta-analysis including $150 \mathrm{MD}$ patients investigated the efficacy of add-on treatment with the NSAID celecoxib. The study concluded that add-on treatment with celecoxib could be promising in such patients. However, the efficacy and tolerability of NSAIDs in depression treatment needs to be confirmed in studies of longer duration and that have a larger sample size. ${ }^{25}$

\section{Statins as an anti-inflammatory therapeutic approach in major depression}

Although used primarily for their lipid-lowering properties, statins also have direct anti-inflammatory effects not mediated by that activity. ${ }^{26,27}$ Therefore, in line with the inflammatory hypothesis of depression, a large population-based study including nearly 900000 selective serotonin reuptake inhibitor (SSRI) users, of whom more than 110000 used a statin concomitantly, investigated the possible antidepressant effect of statins. The concomitant treatment of SSRI and statins resulted in a robust advantage regarding the risk for (a relapse to) depression compared with an SSRI alone. ${ }^{26}$

\section{Other anti-inflammatory therapeutic approaches in depression}

Another anti-inflammatory approach is the use of monoclonal antibodies (mAbs) as cytokine blockers. For example, infliximab is a chimeric monoclonal antibody against TNF- $\alpha$; it prevents TNF- binding to its cell-surface receptors. Initially developed as a treatment for inflammatory joint disorders and psoriasis, it was found to have a significant effect against symptoms of depression in psoriasis patients. ${ }^{28}$ However, a placebo-controlled add-on study using infliximab therapy in depressed patients who were resistant to treatment failed to show an overall antidepressant effect. In that study, 60 patients considered nonresponders to antidepressant therapy-of which 23 were partly medicationfree-received three doses of either infliximab or placebo over a 12-week trial period. Although the infliximab-treated group did not demonstrate an overall better outcome than that of the placebo group, a significant interaction was noted between treatment response and baseline C-reactive protein levels $(\leq 5 \mathrm{mg} / \mathrm{L})$ : a higher response rate to infliximab (62\%) vs placebo $(33 \%)$ was found in those with higher baseline levels of C-reactive protein. Furthermore, infliximab responders had significantly higher baseline levels of TNF- $\alpha$ and soluble TNF receptors 1 and $2(P \leq 0.01)$ than nonresponders, and significantly higher decreases in C-reactive protein levels $(P \leq 0.01) .{ }^{29}$ This finding is especially remarkable, as the study only included treatment-resistant patients.

Interestingly, there are also preliminary findings of anti-inflammatory effects in the CNS, along with improvement in stress and anxiety, associated with blockade of angiotensin II type $1\left(\mathrm{AT}_{1}\right)$ receptors. ${ }^{30,31}$ Moreover, it is probable that treatment resistance to antidepressants such as SSRIs is related to inflammation. ${ }^{32}$

\section{Meta-analysis of anti-inflammatory therapies (NSAIDs and cytokine inhibitors) in major depression}

A recently published meta-analysis including 14 trials (reported in ten publications) on anti-inflammatory treatment in MD ( $\mathrm{n}=6262)$ showed very interesting results: included were 10 trials investigating NSAIDs $(\mathrm{n}=4258)$ and four investigating cytokine inhibitors $(n=2004)$. The pooled effect estimate showed that treatment reduced depressive symptoms compared with pla- 


\section{Pharmacological aspects}

cebo (standardized mean difference [SMD], -0.34; $95 \%$ confidence interval $[\mathrm{CI}],-0.57$ to -0.11 ; heterogeneity statistic $\left.\left[I^{2}\right]=90 \%\right)$. The superiority of treatment over placebo was noted in studies including patients with clinical depression (SMD, $-0.54 ; 95 \%$ CI, -1.08 to -0.01 ; $\left.I^{2}=68 \%\right)$ and those including patients with depressive symptoms (SMD, $-0.27 ; 95 \%$ CI, -0.53 to $-0.01 ; I^{2}=68 \%$ ). The high level of heterogeneity $\left(I^{2}\right)$ observed was not due to differences in the type of depression or treatment. In subanalysis, the antidepressant effect of the NSAID celecoxib (a selective COX-2 inhibitor) stood out, with a trend toward superiority in general (SMD, $-0.29 ; 95 \%$ CI, -0.49 to $-0.08 ; I^{2}=73 \%$ ); when used as an add-on treatment, celecoxib improved remission (odds ratio [OR], 7.89; 95\% CI, 2.94 to $21.17 ; I^{2}=0 \%$ ) and response (OR, 6.59; 95\% CI, 2.24 to $19.42 ; I^{2}=0 \%$ ). Although not all trials reported on adverse effects, in the six that did, no evidence was found for increased gastrointestinal and cardiovascular events over that observed with placebo after 6 weeks of anti-inflammatory treatment, likewise for infections after a 12-week treatment. Of note, the risk of bias associated with all trials was high due to potentially compromised internal validity. Nonetheless, results suggest that anti-inflammatory therapy, especially celecoxib, improves symptoms of depression without increasing the risk for adverse side effects; this proof of concept supports anti-inflammatory therapy use in depression..$^{33}$

\section{The IDO-related pathway in major depression and schizophrenia}

Immune system alterations affect neurotransmission propagated through dopaminergic, noradrenergic, serotonergic, and glutamatergic systems. The metabolism of tryptophan influences neurotransmission propagated through the serotonergic and glutamatergic systems by regulating the enzymatic activity (activation or inhibition) of IDO (mentioned briefly in the section above on NSAIDs in MD). In an activated immune system, some cytokines (eg, interferon- $\gamma[$ IFN- $\gamma]$ and TNF- $\alpha)^{34}$ activate IDO, a key enzyme in the metabolism of tryptophan, whereas other cytokines have an inhibitory effect. Tryptophan/kynurenine metabolism and its potential role in schizophrenia and major depression is depicted in Figure 1 and described here. Inhibiting IDO at the step where it catalyzes the degradation of serotonin (one of the metabolites of tryptophan) into for- myl-5-hydroxykynuramine (f50HKYM) increases serotonin availability, and the neuroactive metabolites of the tryptophan/kynurenine metabolism pathway-kynurenic acid (KYNA) and quinolinic acid (QUIN) - act as an $N$-methyl-D-aspartate (NMDA)-receptor antagonist and an NMDA-receptor agonist, respectively, with very different end effects. In more detail, KYNA is the only known naturally occurring NMDA receptor antagonist in the human CNS. It is formed from kynurenine, the primary major degradation product of tryptophan, with that first rate-limiting step catalyzed by IDO and tryptophan 2,3-dioxygenase (TDO). Kynurenine has other metabolites, 3-hydroxykynurenine and QUIN, which are formed on the path leading to nicotinamide adenine dinucleotide formation; however, KYNA is derived from a separate dead-end path. ${ }^{35}$ KYNA has a dual role: it blocks the glycine coagonist binding site on the NMDA receptor ${ }^{36}$ and noncompetitively inhibits the alpha-7 nicotinic acetylcholine receptor ${ }^{37}$; it thus potentially offers neuroprotection. QUIN, however, is an NMDA-receptor agonist and exhibits neurotoxic effects. It is of interest then that in MD, higher levels of 3-hydroxykynurenine and QUIN have been reported, ${ }^{38}$ whereas in schizophrenia, increased levels of KYNA were observed in serum and cerebrospinal fluid. ${ }^{39}$ The function of these metabolites and the findings in schizophrenia and MD make them interesting candidates for therapeutic interventions in major psychiatric disorders. However, to date, only studies in animal models have been reported. We should consider whether a di-

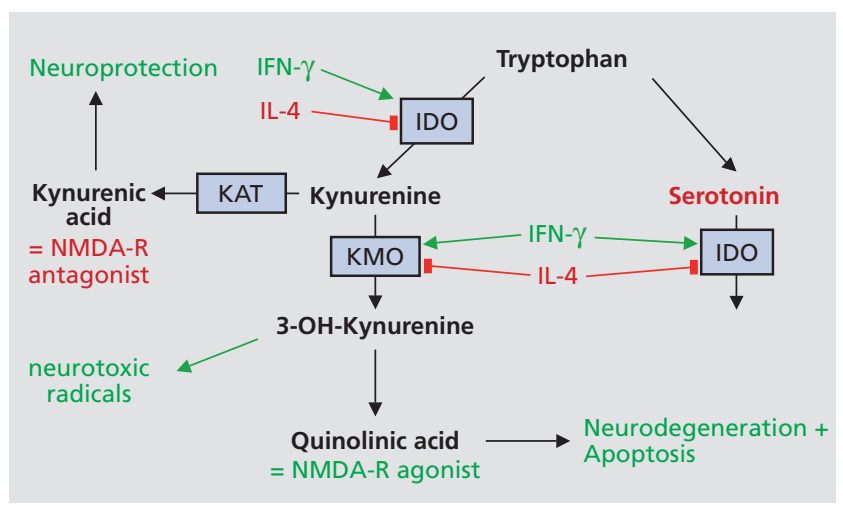

Figure 1. Tryptophan/kynurenine metabolism and its possible role in schizophrenia and major depression. 3-OH-kynurenine, 3-hydroxykynurenine; IDO, indoleamine 2,3-dioxygenase; IFN- $\gamma$, interferon- $\gamma$; IL-4, interleukin 4; KAT, kynurenine aminotransferase I; KMO, kynurenine 3-monooxygenase; NMDA-R, N-methyl-D-aspartate receptor 
rect effect on inflammation could have a better therapeutic impact than the indirect effects of the kynurenine metabolites.

\section{Inflammation and schizophrenia: cytokines, infection, and schizophrenia risk}

It appears that the cytokines IL- $1 \beta$ and IL- 6 have a strong effect on how neurotransmitter systems important in schizophrenia develop; IL-1ß can induce a dopaminergic phenotype in rat mesencephalic progenitor cells, ${ }^{40-42}$ and IL- 6 can decrease the survival of fetal brain serotonergic neurons. ${ }^{43}$ Moreover, it has been shown that the administration of IL-1ß after birth affects dopaminergic neurotransmission in adulthood. However, it is possible that IL-1 and IL-6, mainly released from monocytes of the "innate immune system," only indicate the immune activation state, and their specificity is still unclear.

There is evidence that exposure to infections during the prenatal or perinatal period is a risk factor for schizophrenia, and this notion does not come solely from evidence derived from animal models. ${ }^{44,45}$ In humans, infections-from a number of viral disordershave been investigated as risk factors for schizophrenia. ${ }^{46-48}$ Respiratory infections, ${ }^{49,50}$ genital infections, and reproductive tract infections ${ }^{50,51}$ have been linked to increased risk for schizophrenia in offspring. In pregnant women, infection with Toxoplasma gondii has been closely studied as a potential risk factor for schizophrenia. 52

In humans, elevated maternal levels of IL-8, due to any reason, during pregnancy has been associated with an increased risk for schizophrenia in offspring ${ }^{53}$ and significantly related to decreased brain volume in schizophrenic offspring (more specifically, smaller right posterior cingulate and left entorhinal cortex volumes and larger ventricular volumes). ${ }^{54}$

\section{Infection and increased risk for schizophrenia}

In psychiatry's first large-scale epidemiological study, severe infections and autoimmune disorders were recently shown to additively increase the risk for developing schizophrenia and schizophrenia spectrum disorders. ${ }^{55}$ This was notable as previous studies had mostly investigated the effect of maternal infections during pregnancy (in animal models), and only rarely have studies looked at the effect of infections occurring throughout the lifespan of schizophrenia patients. ${ }^{55,56}$ As infections were only recorded if they led to hospital admission - which would capture only very severe infections - the sensitivity with regard to recording infections was not high. Thus, despite the scale of the study, it is possible that only a small portion of the risk factors were identified. ${ }^{56}$

\section{Cytokine alterations and neuroprogression in schizophrenia}

In schizophrenia patients, high blood and cerebrospinal fluid levels of proinflammatory molecules, including cytokines, have been reported. Imbalances in immune systems-including the innate system (eg, monocytes, macrophages), proinflammatory and anti-inflammatory systems, and type 1 and 2 immunity ${ }^{57}$-in schizophrenia point to an important role for inflammation in the pathophysiology of the disease, in at least a subgroup patients. ${ }^{58,59}$

A specific focus on neuroprogression must consider cytokine levels in different stages of the disease and of treatment. Data clearly reveal that both the stage of the disease and the choice of antipsychotic have an influence on immune function. ${ }^{59,60}$

A meta-analysis that included 40 studies investigating cytokines in schizophrenia at various disease stages and treatment conditions showed that proinflammatory cytokines were significantly elevated. This meta-analysis differentiated between drug-naive first-episode psychosis, an acute relapse of psychosis, and a third group of schizophrenia patients who were stable medicated outpatients with treatment-resistant psychosis. Patients with first-episode schizophrenia and those with acute relapse similarly had higher blood levels of IL- 6 , IFN- $\gamma$, and TNF- $\alpha$ than controls. ${ }^{5}$ However, the third group under antipsychotic treatment showed a significant decrease in IL-6, Il-1ß, and IFN- $\gamma$, and an increase in IL12 and soluble IL-2 receptor. ${ }^{5}$ Whether this is an effect of antipsychotic treatment, chronicity, or both, cannot be determined. It is well-known, however, that antipsychotic treatment has an important impact on cytokine levels.

There are other interfering clinical variables that should be considered, including weight gain, body mass index, smoking, aging, age of onset, duration and se- 


\section{Pharmacological aspects}

verity of the disorder, psychopathological symptoms, and hospitalization. Additionally, laboratory variables should be considered, such as test sensitivity, sample storage, and the mode of release and action of cytokines (eg, IFN- $\gamma$ acts via paracrine signaling through cell-cell contact, whereas TNF- $\alpha$ and IL-6 act through endocrine signaling).

These data show that antipsychotic treatment elicits a different cytokine release pattern that drives most of the cytokine levels in schizophrenic patients toward "normalization." The data consistently show, despite the influence of several interfering variables, that proinflammatory cytokine levels are elevated in schizophrenia. Less clear, however, is the impact that neuroprogression or the schizophrenic state becoming chronic has on immune variables.

\section{The effects of anti-inflammatory treatment in schizophrenia: therapeutic benefit in early stages}

An important argument that inflammation is involved in schizophrenia is the benefit derived from treatment with anti-inflammatory drugs. In particular, adding celecoxib (COX-2 inhibitor) to risperidone treatment in patients with acute exacerbations of schizophrenia led to a better outcome than treatment with risperidone alone in a prospective, randomized, double-blind study ${ }^{61}$ and COX-2 inhibition has pronounced effects on cognition in schizophrenia. ${ }^{62}$ Pooled data $(n=90)$ in a further study of risperidone and celecoxib add-on revealed that patients with a disease duration of 2 years or less benefited from a 6-week celecoxib treatment, whereas the effects of such treatment in those who had the disease for a longer period of time did not differ from the risperidone and placebo group.

Thus, the efficacy of COX-2 inhibitor therapy appears to be most pronounced in the initial years of the disease, confirming the findings of Rapaport and colleagues, who did not find a benefit of COX-2 inhibition in chronic schizophrenia. ${ }^{63}$ Therefore, a celecoxib add-on study was designed for first-episode schizophrenia, which also showed a benefit from celecoxib add-on treatment (add-on to amisulpride) in schizophrenia, not only on the Positive and Negative Syndrome Scale (PANSS) total score, but also on the positive symptom, negative symptom, and general psychopathology scores. ${ }^{64,65}$ Recently, acetylsalicylic acid, a mixed COX-1/COX-2 inhibitor, was shown to have a beneficial effect in schizophrenic spectrum disorders $^{66}$; thus, it would appear that the therapeutic effect of anti-inflammatory treatment is not restricted to COX-2 inhibition. Whereas one meta-analysis of the clinical effects of NSAIDS in schizophrenia showed significant effects on total PANSS scores, as well as subscores for positive and negative symptoms of schizophrenia, ${ }^{67}$ another revealed that only those patients with first-episode schizophrenia or who had the disease for only a short period of time benefited from such treatment. ${ }^{68}$

One could interpret these results to mean that longterm symptoms are associated with poorer anti-inflammatory treatment efficacy in schizophrenia and that efficacy of anti-inflammatory treatment is related to the stage of the disease. However, it is well-known from experience with first- or second-generation antipsychotics that the disease becoming chronic has a negative impact on the outcome in general. As the anti-inflammatory treatment studies discussed here are short-term studies lasting several weeks, it is also taken into account that short-term anti-inflammatory treatment has weak effects in chronic inflammatory diseases. Longer antiinflammatory treatment might show different effects in chronic schizophrenia. ${ }^{69}$

\section{Other immune-related substances in treatment of schizophrenia}

Microglia activation has an important role in inflammation; thus, the antibiotic minocycline-which inhibits microglia activation-is of interest in the treatment of schizophrenia. Indeed, minocycline has been reported to improve cognition in animal models of the disease $\mathrm{e}^{70}$ but also in human schizophrenia patients, evidenced by two double-blind, placebo-controlled trials investigating minocycline as an add-on therapy. ${ }^{71,72}$ It has also demonstrated positive effects on the negative symptoms of schizophrenia in clinical studies. ${ }^{71}$ Furthermore, beneficial effects of minocycline treatment on the entire range of schizophrenia symptoms have been described in case reports. ${ }^{73}$

Schizophrenic patients have been shown to receive some benefit from treatment with acetylcysteine and other molecules, such as omega-3 fatty acids, with antiinflammatory effects, among others (see reference 74 for an overview). 
Although results are preliminary, initial pilot trials treating schizophrenia using IFN- $\gamma$ to stimulate the monocytic type 1 immune response have been encouraging $^{75}$; however, patients must be closely monitored for adverse side effects, including unwanted effects on the immune system. Nevertheless, an immune-based approach opens the door to new possibilities for therapeutic development based on the etiopathology of schizophrenia.

The use of mAbs is an emerging topic for schizophrenia therapy. However, there is no convincing data that they are currently useful in schizophrenia. Nonetheless, there is rationale based on cytokine data for the development of compelling, carefully planned clinical trials with mABs. ${ }^{76}$ Indeed, studies using mABs against IL-6 and soluble IL-6 receptor are on the way.

\section{REFERENCES}

1. Wagner von Jauregg J. Fieberbehandlung bei Psychosen. Wien Med Wochenschr. 1926;76:79-82.

2. Zipursky RB, Menezes NM, Streiner DL. Risk of symptom recurrence with medication discontinuation in first-episode psychosis: a systematic review. Schizophr Res. 2014;152(2-3):408-414.

3. Maes M. Cytokines in major depression. Biol Psychiatry. 1994;36(7):498499.

4. Maes M, Stevens W, DeClerck L, et al. Immune disorders in depression: higher T helper/T suppressor-cytotoxic cell ratio. Acta Psychiatr Scand. 1992;86(6):423-431.

5. Miller BJ, Buckley P, Seabolt W, Mellor A, Kirkpatrick B. Meta-analysis of cytokine alterations in schizophrenia: clinical status and antipsychotic effects. Biol Psychiatry. 2011;70(7):663-671.

6. Muller N, Hofschuster E, Ackenheil M, Mempel W, Eckstein R. Investigations of the cellular immunity during depression and the free interval: evidence for an immune activation in affective psychosis. Prog Neuropsychopharmacol Biol Psychiatry. 1993;17(5):713-730.

7. Myint AM, Leonard BE, Steinbusch HW, Kim YK. Th1, Th2, and Th3 cytokine alterations in major depression. J Affect Disord. 2005;88(2):167173.

8. Potvin S, Stip E, Sepehry AA, Gendron A, Bah R, Kouassi E. Inflammatory cytokine alterations in schizophrenia: a systematic quantitative review. Biol Psychiatry. 2008;63(8):801-808.

9. Rothermundt $\mathrm{M}$, Arolt $\mathrm{V}$, Peters $\mathrm{M}$, et al. Inflammatory markers in major depression and melancholia. J Affect Disord. 2001;63(1-3):93-102.

10. Dowlati Y, Herrmann N, Swardfager W, et al. A meta-analysis of cytokines in major depression. Biol Psychiatry. 2010;67(5):446-457.

11. Howren MB, Lamkin DM, Suls J. Associations of depression with C-reactive protein, IL-1, and IL-6: a meta-analysis. Psychosom Med. 2009; 71(2):171-186.

12. Song $C$, Lin $A$, Bonaccorso $S$, et al. The inflammatory response system and the availability of plasma tryptophan in patients with primary sleep disorders and major depression. J Affect Disord. 1998;49(3):211-219.

13. Calabrese JR, Skwerer RG, Barna B, et al. Depression, immunocompetence, and prostaglandins of the E series. Psychiatry Res. 1986;17(1):41-47.

14. Linnoila M, Whorton AR, Rubinow DR, Cowdry RW, Ninan PT, Waters RN. CSF prostaglandin levels in depressed and schizophrenic patients. Arch Gen Psychiatry. 1983;40(4):405-406.

\section{Conclusion}

Emerging evidence points to a role of the inflammatory process in the pathogenesis of major psychiatric disorders. Accordingly, during the last decade, anti-inflammatory therapeutic approaches have been studied in schizophrenia and depression. COX-2 inhibitors show beneficial effects in the early stages of schizophrenia, and promising results have been obtained for MD. Moreover, interesting results come from studies with other antiinflammatory compounds, including antibodies against IL-6 and TNF- $\alpha$. Intensive research, however, is necessary in order to clarify whether an immune-related therapy may one day replace treatment with the currently available antidepressants or antipsychotics, at least in subgroups of patients with MD or schizophrenia. $\square$

Conflict of interest: None to declare.

15. Nishino S, Ueno R, Ohishi K, Sakai T, Hayaishi O. Salivary prostaglandin concentrations: possible state indicators for major depression. Am J Psychiatry. 1989;146(3):365-368.

16. Ohishi K, Ueno R, Nishino S, Sakai T, Hayaishi O. Increased level of salivary prostaglandins in patients with major depression. Biol Psychiatry. 1988;23(4):326-334.

17. Sandrini M, Vitale G, Pini LA. Effect of rofecoxib on nociception and the serotonin system in the rat brain. Inflamm Res. 2002;51(3):154-159.

18. Myint AM, Kim YK, Verkerk R, Scharpe S, Steinbusch H, Leonard B. Kynurenine pathway in major depression: evidence of impaired neuroprotection. J Affect Disord. 2007;98(1-2):143-151.

19. Brunello N, Alboni S, Capone G, et al. Acetylsalicylic acid accelerates the antidepressant effect of fluoxetine in the chronic escape deficit model of depression. Int Clin Psychopharmacol. 2006;21(4):219-225.

20. Muller N, Schwarz MJ, Dehning S, et al. The cyclooxygenase-2 inhibitor celecoxib has therapeutic effects in major depression: results of a double-blind, randomized, placebo controlled, add-on pilot study to reboxetine. Mol Psychiatry. 2006;11(7):680-684.

21. Krause D, Myint A-M, Schuett $C$, Musil R, Dehning S, Cerovecki A, Riedel M, Arolt V, Schwarz MJ and Müller N. High kynurenine (a tryptophan metabolite) predicts remission in patients with major depression to add-on treatment with celecoxib. Front Psychiatry. 8:16. doi: 10.3389/ fpsyt.2017.00016.

22. Akhondzadeh S, Jafari S, Raisi F, Ghoreishi A. A clinical trial of adjunctive celecoxib treatment in patients with major depression: a double blind and placebo controlled trial. World Psychiatric Association Section on Immunology and Psychiatry - Psychoneuroimmunology Training Workshop; July 11-13, 2008; Seeon, Munich, Germany.

23. Akhondzadeh S, Jafari S, Raisi F, et al. Clinical trial of adjunctive celecoxib treatment in patients with major depression: a double blind and placebo controlled trial. Depress Anxiety. 2009;26(7):607-611.

24. Abbasi SH, Hosseini F, Modabbernia A, Ashrafi M, Akhondzadeh S. Effect of celecoxib add-on treatment on symptoms and serum IL-6 concentrations in patients with major depressive disorder: randomized doubleblind placebo-controlled study. J Affect Disord. 2012;141(2-3):308-314.

25. Na KS, Lee KJ, Lee JS, Cho YS, Jung HY. Efficacy of adjunctive celecoxib treatment for patients with major depressive disorder: a meta-analysis. Prog Neuropsychopharmacol Biol Psychiatry. 2014;48:79-85.

26. Kohler O, Gasse $C$, Petersen L, et al. The effect of concomitant treatment with SSRIs and statins: a population-based study. Am J Psychiatry. 2016;173(8):807-815. 


\section{Pharmacological aspects}

27. Weitz-Schmidt G. Statins as anti-inflammatory agents. Trends Pharmacol Sci. 2002;23(10):482-486.

28. Tyring S, Gottlieb A, Papp K, et al. Etanercept and clinical outcomes, fatigue, and depression in psoriasis: double-blind placebo-controlled randomised phase III trial. Lancet. 2006;367(9504):29-35.

29. Raison $\mathrm{CL}$, Rutherford RE, Woolwine $\mathrm{BJ}$, et al. A randomized controlled trial of the tumor necrosis factor antagonist infliximab for treatment-resistant depression: the role of baseline inflammatory biomarkers. JAMA Psychiatry. 2013;70(1):31-41.

30. Benicky J, Sanchez-Lemus E, Honda M, et al. Angiotensin II AT, receptor blockade ameliorates brain inflammation. Neuropsychopharmacology. 2011;36(4):857-870.

31. Saavedra JM, Sanchez-Lemus E, Benicky J. Blockade of brain angiotensin II AT, receptors ameliorates stress, anxiety, brain inflammation and ischemia: therapeutic implications. Psychoneuroendocrinology. 2011;36(1):118.

32. Lanquillon S, Krieg JC, Bening-Abu-Shach U, Vedder H. Cytokine production and treatment response in major depressive disorder. Neuropsychopharmacology. 2000;22(4):370-379.

33. Kohler O, Benros ME, Nordentoft M, et al. Effect of anti-inflammatory treatment on depression, depressive symptoms, and adverse effects: a systematic review and meta-analysis of randomized clinical trials. JAMA Psychiatry. 2014;71(12):1381-1391.

34. Grohmann U, Fallarino F, Puccetti P. Tolerance, DCs and tryptophan: much ado about IDO. Trends Immunol. 2003;24(5):242-248.

35. Schwarcz R, Pellicciari R. Manipulation of brain kynurenines: glial targets, neuronal effects, and clinical opportunities. J Pharmacol Exp Ther. 2002;303(1):1-10.

36. Kessler M, Terramani T, Lynch G, Baudry M. A glycine site associated with $\mathrm{N}$-methyl-D-aspartic acid receptors: characterization and identification of a new class of antagonists. J Neurochem. 1989:52(4):1319-1328.

37. Hilmas C, Pereira EF, Alkondon M, Rassoulpour A, Schwarcz R, Albuquerque EX. The brain metabolite kynurenic acid inhibits alpha7 nicotinic receptor activity and increases non-alpha7 nicotinic receptor expression: physiopathological implications. J Neurosci. 2001;21(19):7463-7473.

38. Savitz J, Drevets WC, Wurfel BE, et al. Reduction of kynurenic acid to quinolinic acid ratio in both the depressed and remitted phases of major depressive disorder. Brain Behav Immun. 2015;46:55-59.

39. Kegel ME, Bhat M, Skogh $E$, et al. Imbalanced kynurenine pathway in schizophrenia. Int J Tryptophan Res. 2014;7:15-22.

40. Kabiersch A, Furukawa $\mathrm{H}$, del Rey A, Besedovsky HO. Administration of interleukin-1 at birth affects dopaminergic neurons in adult mice. Ann N Y Acad Sci. 1998;840:123-127.

41. Ling ZD, Potter ED, Lipton JW, Carvey PM. Differentiation of mesencephalic progenitor cells into dopaminergic neurons by cytokines. Exp Neurol. 1998;149(2):411-423.

42. Potter ED, Ling ZD, Carvey PM. Cytokine-induced conversion of mesencephalic-derived progenitor cells into dopamine neurons. Cell Tissue Res. 1999;296(2):235-246.

43. Jarskog LF, Xiao H, Wilkie MB, Lauder JM, Gilmore JH. Cytokine regulation of embryonic rat dopamine and serotonin neuronal survival in vitro. Int J Dev Neurosci. 1997;15(6):711-716.

44. Buka SL, Tsuang MT, Torrey EF, Klebanoff MA, Bernstein D, Yolken RH. Maternal infections and subsequent psychosis among offspring. Arch Gen Psychiatry. 2001;58(11):1032-1037.

45. Westergaard T, Mortensen PB, Pedersen CB, Wohlfahrt J, Melbye $M$. Exposure to prenatal and childhood infections and the risk of schizophrenia: suggestions from a study of sibship characteristics and influenza prevalence. Arch Gen Psychiatry. 1999;56(11):993-998.

46. Brown AS, Begg MD, Gravenstein S, et al. Serologic evidence of prenatal influenza in the etiology of schizophrenia. Arch Gen Psychiatry. 2004;61(8):774-780

47. Buka SL, Cannon TD, Torrey EF, Yolken RH. Maternal exposure to herpes simplex virus and risk of psychosis among adult offspring. Biol Psychiatry. 2008:63(8):809-815.

48. Pearce BD. Schizophrenia and viral infection during neurodevelopment: a focus on mechanisms. Mol Psychiatry. 2001;6(6):634-646.

49. Brown AS, Cohen P, Greenwald S, Susser E. Nonaffective psychosis after prenatal exposure to rubella. Am J Psychiatry. 2000;157(3):438-443.
50. Sorensen HJ, Mortensen EL, Reinisch JM, Mednick SA. Association between prenatal exposure to bacterial infection and risk of schizophrenia. Schizophr Bull. 2009;35(3):631-637.

51. Babulas V, Factor-Litvak P, Goetz R, Schaefer CA, Brown AS. Prenatal exposure to maternal genital and reproductive infections and adult schizophrenia. Am J Psychiatry. 2006;163(5):927-929.

52. Brown AS, Schaefer CA, Quesenberry CP Jr, Liu L, Babulas VP, Susser ES. Maternal exposure to toxoplasmosis and risk of schizophrenia in adult offspring. Am J Psychiatry. 2005;162(4):767-773.

53. Brown AS, Hooton J, Schaefer CA, et al. Elevated maternal interleukin-8 levels and risk of schizophrenia in adult offspring. Am J Psychiatry. 2004;161(5):889-895.

54. Ellman LM, Deicken RF, Vinogradov $S$, et al. Structural brain alterations in schizophrenia following fetal exposure to the inflammatory cytokine interleukin-8. Schizophr Res. 2010;121(1-3):46-54.

55. Benros ME, Nielsen PR, Nordentoft $M$, Eaton WW, Dalton SO, Mortensen PB. Autoimmune diseases and severe infections as risk factors for schizophrenia: a 30-year population-based register study. Am J Psychiatry. 2011;168(12):1303-1310.

56. Benros ME, Mortensen PB, Eaton WW. Autoimmune diseases and infections as risk factors for schizophrenia. Ann N Y Acad Sci. 2012;1262:5666.

57. Sperner-Unterweger B, Barnas C, Fuchs D, et al. Neopterin production in acute schizophrenic patients: an indicator of alterations of cellmediated immunity. Psychiatry Res. 1992;42(2):121-128.

58. Muller N, Schwarz MJ. Immune system and schizophrenia. Curr Immunol Rev. 2010;6(3):213-220.

59. Muller N, Ackenheil M, Hofschuster E, Mempel W, Eckstein R. Cellular immunity in schizophrenic patients before and during neuroleptic treatment. Psychiatry Res. 1991;37(2):147-160.

60. Muller N, Empl M, Riedel M, Schwarz M, Ackenheil M. Neuroleptic treatment increases soluble IL-2 receptors and decreases soluble IL-6 receptors in schizophrenia. Eur Arch Psychiatry Clin Neurosci. 1997;247(6):308-313. 61. Muller N, Riedel M, Scheppach C, et al. Beneficial antipsychotic effects of celecoxib add-on therapy compared to risperidone alone in schizophrenia. Am J Psychiatry. 2002;159(6):1029-1034.

62. Muller N, Riedel M, Schwarz MJ, Engel RR. Clinical effects of COX-2 inhibitors on cognition in schizophrenia. Eur Arch Psychiatry Clin Neurosci. 2005:255(2):149-151.

63. Rapaport MH, Delrahim KK, Bresee CJ, Maddux RE, Ahmadpour O, Dolnak D. Celecoxib augmentation of continuously ill patients with schizophrenia. Biol Psychiatry. 2005;57(12):1594-1596.

64. Muller N. COX-2 inhibitors as antidepressants and antipsychotics: clinical evidence. Curr Opin Investig Drugs. 2010;11(1):31-42.

65. Muller N, Krause D, Dehning S, et al. Celecoxib treatment in an early stage of schizophrenia: results of a randomized, double-blind, placebocontrolled trial of celecoxib augmentation of amisulpride treatment. Schizophr Res. 2010;121(1-3):118-124.

66. Laan W, Grobbee DE, Selten JP, Heijnen CJ, Kahn RS, Burger H. Adjuvant aspirin therapy reduces symptoms of schizophrenia spectrum disorders: results from a randomized, double-blind, placebo-controlled trial. $J$ Clin Psychiatry. 2010;71(5):520-527.

67. Sommer IE, de Witte L, Begemann M, Kahn RS. Nonsteroidal antiinflammatory drugs in schizophrenia: ready for practice or a good start? A meta-analysis. J Clin Psychiatry. 2012;73(4):414-419.

68. Nitta M, Kishimoto T, Muller N, et al. Adjunctive use of nonsteroidal anti-inflammatory drugs for schizophrenia: a meta-analytic investigation of randomized controlled trials. Schizophr Bull. 2013;39(6):1230-1241. 69. Akhondzadeh S, Tabatabaee M, Amini H, Ahmadi Abhari SA, Abbasi $\mathrm{SH}$, Behnam B. Celecoxib as adjunctive therapy in schizophrenia: a double-blind, randomized and placebo-controlled trial. Schizophr Res. 2007;90(1-3):179-185.

70. Mizoguchi H, Takuma K, Fukakusa A, et al. Improvement by minocycline of methamphetamine-induced impairment of recognition memory in mice. Psychopharmacology (Berl). 2008;196(2):233-241.

71. Chaudhry IB, Hallak J, Husain N, et al. Minocycline benefits negative symptoms in early schizophrenia: a randomised double-blind placebocontrolled clinical trial in patients on standard treatment. J Psychopharmacol. 2012;26(9):1185-1193. 
72. Levkovitz Y, Mendlovich S, Riwkes S, et al. A double-blind, randomized study of minocycline for the treatment of negative and cognitive symptoms in early-phase schizophrenia. J Clin Psychiatry. 2010;71(2):138-149.

73. Ahuja N, Carroll BT. Possible anti-catatonic effects of minocycline in patients with schizophrenia. Prog Neuropsychopharmacol Biol Psychiatry. 2007;31(4):968-969.

74. Sommer IE, van Westrhenen R, Begemann MJ, de Witte LD, Leucht

$\mathrm{S}$, Kahn RS. Efficacy of anti-inflammatory agents to improve symptoms in patients with schizophrenia: an update. Schizophr Bull. 2014;40(1):181191.

75. Gruber L, Bunse T, Weidinger E, Reichard H, Muller N. Adjunctive recombinant human interferon gamma-1b for treatment-resistant schizophrenia in 2 patients. J Clin Psychiatry. 2014;75(11):1266-1267.

76. Miller BJ, Buckley PF. The case for adjunctive monoclonal antibody immunotherapy in schizophrenia. Psychiatr Clin North Am. 2016;39(2):187198. 


\section{Aspectos inmunológicos en el tratamiento de la depresión y la esquizofrenia}

La esquizofrenia y la depresión mayor (DM) se han asociado con una disfunción del sistema inmune, como lo demuestra la alteración en el nivel sanguíneo de citoquinas-importantes mediadores inflamatorios- $y$ un estado inmune proinflamatorio descrito en algunos subgrupos de pacientes. Una agresión al sistema inmune en edades precoces puede gatillar un aumento de la reactividad inmune a lo largo de la vida. Hoy se sabe que las infecciones y los trastornos inmunes constituyen factores de riesgo para el desarrollo de la esquizofrenia y la DM. Las citoquinas pro y anti-inflamatorias median la actividad de la indolamina 2,3 dioxigenasa, enzima que estimula el metabolismo del triptófano y la quinurenina en el sistema nervioso central y que degrada la serotonina. Los resultados de meta-análisis han asociado la alteración de la neurotransmisión serotoninérgica, noradrenérgica y glutamatérgica con bajos niveles de neuroinflamación, y el beneficio terapéutico de los compuestos antiinflamatorios en la DM y en la esquizofrenia. Además, los antidepresivos y los antipsicóticos tienen efectos inmunomoduladores intrínsecos. Este artículo revisa varios aspectos inmunológicos del tratamiento de importantes trastornos psiquiátricos, de acuerdo con la evidencia que apunta al papel que juegan los procesos inflamatorios en la patogénesis de estos trastornos.

\section{Aspects immunologiques du traitement de la dépression et de la schizophrénie}

Schizophrénie et dépression caractérisée sont associées à une dysfonction du système immunitaire comme le montrent l'altération du taux de cytokines (médiateurs inflammatoires importants) dans le sang et l'état immunitaire pro-inflammatoire décrit chez certains sous-groupes de patients. Une atteinte précoce du système immunitaire peut déclencher une augmentation de la réactivité immunitaire tout au long de la vie, les infections et les troubles auto-immuns étant connus aujourd'hui pour être des facteurs de risque de développement de schizophrénie et de dépression caractérisée. Les cytokines pro- et anti-inflammatoires sont les médiateurs de l'activité de l'indoléamine 2,3-dioxygénase, enzyme qui stimule le métabolisme du tryptophane et de la kynurénine dans le système nerveux central et qui dégrade la sérotonine. II existe une association entre des modifications de la neurotransmission sérotoninergique, noradrénergique et glutamatergique et une neuro-inflammation de faible niveau; de plus, des méta-analyses montrent un bénéfice thérapeutique des anti-inflammatoires dans la schizophrénie et la dépression caractérisée. D'autre part, les antidépresseurs et les antipsychotiques ont des effets immunomodulateurs intrinsèques. Cet article s'intéresse aux différents aspects immunologiques du traitement des troubles psychiatriques caractérisés en soulignant les données en faveur du rôle joué par les processus inflammatoires dans leur pathogenèse. 